\author{
Marquette University \\ e-Publications@Marquette
}

Biomedical Sciences Faculty Research and

Publications

Biomedical Sciences, Department of

4-1960

\title{
Transformation of Neisseria meningitidis by Deoxyribonucleates from Cells and from Culture Slime
}

B. Wesley Catlin

Marquette University

Follow this and additional works at: https://epublications.marquette.edu/biomedsci_fac

Part of the Neurosciences Commons

\section{Recommended Citation}

Catlin, B. Wesley, "Transformation of Neisseria meningitidis by Deoxyribonucleates from Cells and from Culture Slime" (1960). Biomedical Sciences Faculty Research and Publications. 127.

https://epublications.marquette.edu/biomedsci_fac/127 


\title{
TRANSFORMATION OF NEISSERIA MENINGITIDIS BY DEOXYRIBONUCLEATES FROM CELLS AND FROM CULTURE SLIME ${ }^{1}$
}

\author{
B. WESLEY CATLIN \\ Department of Microbiology and Immunology, School of Medicine, Marquette University, \\ Milwaukee, Wisconsin
}

Received for publication August 31, 1959

Highly polymerized deoxyribonucleate (DNA) is a component of some slimes that accumulate in ordinary broth cultures of a variety of bacteria (Smithies and Gibbons, 1955; Catlin, 1956a). Such DNA, designated as extracellular, may be distinguished from intracellular DNA of the same culture by its accessibility to crystalline pancreatic deoxyribonuclease. Small quantities of this enzyme destroy the sticky consistency of the DNA-containing slime. DNA within intact cells, however, is not affected by added deoxyribonuclease and, subsequent to enzyme action, may be isolated in a highly polymerized form by disrupting the washed cells in a medium that inhibits deoxyribonuclease.

The origin of extracellular DNA may be obscured, in some cases, by cryptic multiplication. Investigation of Micrococcus halodenitrificans using radioactive phosphorus-labeled cells has shown that the DNA in culture slime was of intracellular origin (Takahashi and Gibbons, 1957). When this halophilic organism was cultivated in suboptimal concentrations of sodium chloride, some cells of the population apparently ruptured, releasing nucleic acid; much of the DNA adhered to the cells, whereas the ribonucleate diffused into the medium. Cellular lysis, also, can account for the DNA present extracellularly in cultures of Pseudomonas fluorescens (Catlin, unpublished data) and Neisseria meningitidis. In other cases the source remains to be determined.

Extracellular accumulation of highly polymerized DNA can occur only in the absence of deoxyribonuclease activity. Staphylococcus aureus, $P$. fluorescens, and Alcaligenes faecalis produce enzymes which are different, but which have

1 This investigation was supported by research grants C-2405 (c) and E-2353 from the National Institute of Allergy and Infectious Diseases, U. S. Public Health Service. in common the capacity to depolymerize certain DNA preparations. Under the proper circumstances these enzymes apparently were inactive, and extracellular DNA accumulated in cultures (Catlin, 1956b; Catlin and Cunningham, 1958). It was not certain that such DNA had escaped damage entirely. If structurally intact, however, extracellular DNA might possess genetic information. This possibility, which is important from the standpoint of population dynamics, has been explored using $N$. meningitidis.

Selection of the meningococcus for this study was based on its formation of slime in cultures without experimental intervention, and its capacity for DNA-conferred genetic change (transformation). Alexander and Redman (1953) demonstrated transformation of type IIa meningococci (either $\mathrm{R}$ or $\mathrm{S}$ ) to type I under the influence of DNA-containing extracts from type I cells. Their method of detecting transformation did not lend itself readily to a quantitative approach. Therefore, antibiotic resistance transformations were investigated as a basis for developing a quantitative method (Hotchkiss, 1957), which could be used to compare the genetic activities of meningococcus DNA preparations.

Quantitative transformation tests involving antibiotic resistance markers are carried out in four main steps. (1) Cells are cultivated in an environment and for a period of time designed to bring the greatest proportion of the population to a state of competence, i. e., capacity to become transformed. (2) These cells are mixed under suitable conditions with a known concentration of DNA. After a brief exposure period, crystalline deoxyribonuclease is added to destroy the activity of DNA that has not been irreversibly bound by the cells. A sample of the population is assayed at this time to determine the number of exposed cells per $\mathrm{ml}(E)$. (3) The population is allowed to carry out metabolic activities for a 
period long enough to assure development of the transformant phenotype by each of the modified cells. (4) Before the transformed cells undergo division, the population is brought into a selective environment which will inhibit reproduction of the untransformed cells, but will allow colony formation by each of the transformants (number of transformants per $\mathrm{ml}=T$ ). The transformation ratio $(T: E)$ may be calculated from these data.

Investigations of these steps, which were required for developing and for evaluating the method, will be summarized in Part I in the Results section. Part II will present results of comparative studies of meningococcus DNA preparations from intracellular and from extracellular locations.

\section{MATERIALS AND METHODS}

Strains and antibiotics. N. meningitidis strains 10 and 15 from the departmental culture collection, and variants derived from them by mutation and by transformation, were used exclusively. Both strains were isolated from spinal fluid from cases of fatal (nonepidemic) meningitis, and after a minimal number of transfers were retained frozen (at $-60 \mathrm{C}$ ). They are typical gram-negative diplococci, which are oxidase positive, and ferment glucose and maltose (lactose, mannitol, and sucrose tests are negative). Aerobic incubation at $37 \mathrm{C}$ of cultures on moist blood agar or infusion media results within 2 days in colonies having a diameter of $4 \mathrm{~mm}$. Isolated colonies are visible within $10 \mathrm{hr}$. A waterjacketed (National) incubator was used to avoid growth restriction associated with drying of agar surfaces.

Both strains were highly sensitive to all antibiotics tested. Antibiotic resistant strains used in the experiments reported were derived by the following methods. Strain 15 ery-r, resistant to 3 $\mu \mathrm{g}$ per ml erythromycin (Erythrocin lactobionate, Abbott), and strain 15 car-r, resistant to $50 \mu \mathrm{g}$ per $\mathrm{ml}$ carbomycin (Magnamycin, generously provided by Chas. Pfizer and Co., Inc.) were obtained by repeated exposure to increasing concentrations of each antibiotic, using the gradient plate technique (Szybalski, 1952).

Crystalline dihydrostreptomycin sulfate (Squibb) was used for all studies involving streptomycin-resistant (str-r) and streptomycindependent (str-d) strains (Miller and Bohnhoff,
1947). Strain 10 str-r and strain 15 str- $d$ arose during cultivation of the respective str-sensitive $(s t r-s)$ strains in shaken flasks of brain heart infusion; after a primary incubation period of $18 \mathrm{hr}$, a quantity of $s t r$ sufficient to give $500 \mu \mathrm{g}$ per $\mathrm{ml}$ was added. The flasks were reincubated for $20 \mathrm{hr}$ to allow replication of the mutants, which were recovered upon subsequent inoculation of an agar medium (HI-1, see below) containing 500 or $1000 \mu \mathrm{g}$ str per ml. A single isolated colony (per original flask) was used to establish a strain. Strain 15 str-r 51 was obtained by transformation, following treatment of strain 15 str-s with DNA extracted from strain 10 str-r. Strain 15 str-d differed from the str- $r$ strains in its requirement for streptomycin $(15 \mu \mathrm{g}$ per $\mathrm{ml}$ or more) for unlimited multiplication.

Media. Brain heart infusion (Difco) and heart infusion broth (Difco) supported growth of these meningococci when relatively large inocula were used. Heart infusion broth was more satisfactory when supplemented with ribonucleic acid $(\mathrm{Nu}-$ tritional Biochemicals Corporation), $250 \mu \mathrm{g}$ per $\mathrm{ml}$; sodium glutamate, $0.00005 \mathrm{~m}$; and calcium chloride, 0.0005 i (separately added sterile solutions). In this medium, designated HI-1, growth of strain 15 was initiated using fewer than $10^{5}$ cells per $\mathrm{ml}$, and generation times were 31 to $33 \mathrm{~min}(29 \mathrm{~min}$ with addition of 0.2 per cent glucose).

HI-1 with agar (Difco) added made a suitable solid medium for meningococcal growth. Concentrations of agar employed were 1.4 per cent (hard agar) or 0.7 per cent (soft agar). HI-1 agar with addition (before sterilization) of yeast extract (Difco), 0.3 per cent (by weight), was the plating medium routinely employed in transformation tests (HIY-1 agar); as before, the three supplements were added aseptically after sterilization.

Another fluid medium, HI-2, used in some experiments was heart infusion broth supplemented with 10 per cent (by volume) fresh yeast extract, 10 per cent standard salt mixture, and 0.2 per cent glucose. The salt mixture was composed of $\mathrm{NH}_{4} \mathrm{Cl}, 2 \mathrm{~g} ; \mathrm{Na}_{2} \mathrm{HPO}_{4}, 6 \mathrm{~g} ; \mathrm{KH}_{2} \mathrm{PO}_{4}$, $3 \mathrm{~g}$; $\mathrm{NaCl}, 3 \mathrm{~g} ; \mathrm{Mg}$ (as $\mathrm{MgCl}_{2}$ ), $10 \mathrm{mg}$; $\mathrm{S}$ (as $\left.\mathrm{Na}_{2} \mathrm{SO}_{4}\right), 25 \mathrm{mg}$; distilled water $900 \mathrm{ml}$. Yeast extract was prepared from fresh filter press yeast (a gift from Red Star Yeast and Products Company, Milwaukee). The yeast cells, suspended in distilled water, were disrupted with 
borosilicate beads in a mechanical shaker; the extract was washed from the beads, centrifuged, and sterilized by Seitz filtration.

DNA preparations. Extracellular DNA was obtained from the supernatant broths of slimy cultures ranging in age from 2 to 6 days (see Part II). The slime was dispersed by hand shaking, and the culture was centrifuged (3000 $\times \mathrm{G}, 1 \mathrm{hr}, 8 \mathrm{C})$. The supernatant broth was decanted into a beaker, which was rotated vigorously by hand in a horizontal plane while 95 per cent ethanol ( 2 volumes) was added slowly. Ideally, the resulting fibrous precipitate could be lifted out as an intact web to separate it from the fluid in which a flocculent precipitate was forming; occasionally, it was necessary to collect the precipitate by centrifugation. The fibers, washed in 75 per cent ethanol and freed of excess fluid, were dissolved in $1 \mathrm{M} \mathrm{NaCl}$ with overnight stirring at $3 \mathrm{C}$. The resulting solution was centrifuged $(32,000 \times \mathrm{G}, 1 \mathrm{hr}, 3 \mathrm{C})$ and, from the supernatant fluid, a fibrous precipitate was obtained by addition of 1 volume of ethanol. The fibers were lifted, washed in 75 per cent ethanol, and dissolved in a solution containing $\mathrm{NaCl}$ $(0.14 \mathrm{M})$ and sodium citrate $(0.015 \mathrm{M}$; "standard buffer" of Zamenhof et al., 1953). Solutions of crude extracellular DNA were subjected to deproteinization with sodium dodecyl sulfate, as previously described (Catlin and Cunningham. 1958).

Intracellular DNA was obtained by lysing cellular suspensions with detergent. The cells were obtained by centrifugation of 16-hr $\mathrm{Hl}-1$. broth cultures or, more commonly and in higher yield, by washing off the surface growth from cultures on HI-1 agar (2.0 per cent agar) in large dishes (incubation for 16 to $18 \mathrm{hr}$ at $37 \mathrm{C}$, with humidity increased to 70 per cent). To the cells, suspended in minimal amounts of standard buffer solution, finely powdered recrystallized sodium dodecyl sulfate was slowly added to a final concentration of 1 to 5 per cent; the fluid, at room temperature, was subjected to slow mechanical stirring. When lysis was essentially complete (60 to $120 \mathrm{~min}$ ), microscopic inspection revealed only a few intact cells per oil immersion field. The massive fibrous precipitate, which formed upon addition (see procedure, above) of 2 volumes of 95 per cent ethanol, was lifted or removed by centrifugation if necessary, and was dissolved in $1 \mathrm{M} \mathrm{NaCl}$ solution with overnight stirring at $3 \mathrm{C}$. Further procedures were similar to those described for extracellular DNA. Two transforming preparations were subjected to more extensive purification, involving cetyltrimethylammonium bromide and calcium chloride steps (Catlin and Cunningham, 1958). Care was taken at all times to avoid dehydration and exposure to low ionic concentration, which reduce transforming activity (Zamenhof et al., 1953).

Fibers obtained from the final ethanol precipitation were soaked in 75 per cent ethanol at room temperature for 2 to $3 \mathrm{hr}$. Using sterile glassware and aseptic precautions, excess alcohol was pressed out by rolling a stirring rod to flatten the fibers against the side of a beaker. The fibers dissolved in sterile solutions of $0.14 \mathrm{M} \mathrm{NaCl}$ or of standard buffer were stored at $3 \mathrm{C}$ or were frozen at $-20 \mathrm{C}$. Solutions of all DNA preparations proved to be sterile. DNA concentration was determined by the diphenylamine reaction (Dische, 1955).

Deoxyribonuclease. Crystalline pancreatic deoxyribonuclease (sterile, Worthington) was dissolved, $10 \mathrm{mg}$ per ml., in sterile 2 per cent gelatin solution, and was stored at $3 \mathrm{C}$. Immediately before use, a mixture was prepared in the proportion 1 part deoxyribonuclease to 4 parts $2 \mathrm{~m}$ $\mathrm{MgCl}_{2}$ to 5 parts 2 per cent gelatin. A quantity of mixture sufficient to give 5 to $10 \mu \mathrm{g}$ enzyme per $\mathrm{ml}$ destroyed transforming activity in less than 1 min.

Recipient cells. Strain 15, and mutants derived from it, were the recipients in all transformation tests reported. Except where competence was being investigated specifically, cells to be exposed to transforming DNA were taken from cultures on HI-1 agar or blood agar which had been incubated 11 to $17 \mathrm{hr}$ at $37 \mathrm{C}$. A small amount of growth from a number of punctiform colonies was dispersed in warm HI-1 broth or other exposure medium. Suspensions having a slight visible turbidity contained about $10^{7}$ colonyforming units per ml. Microscopic examination of wet mounts showed 25 to 50 per cent paired cells, and not more than 1 to 2 per cent of larger aggregates, whereas the remainder apparently were single cells. The suspension (further diluted $1: 10$ to $1: 100$ in warm medium, as required) was mixed immediately with DNA at $36 \mathrm{C}$; deoxyribonuclease commonly was added 15 min later.

Assays. Total number of colony-forming units (= viable "cells") was determined by adding 
measured volumes of an appropriate dilution of cells to 4-ml amounts of HIY-1 soft agar (liquefied and retained in a water bath at $44 \mathrm{C}$ ). Inoculated agar was poured without delay on top of supporting layers of solidified HIY-1 hard agar. Counts of numbers of colonies on triplicate plates, incubated 2 to 3 days at $37 \mathrm{C}$, agreed within 10 per cent. In contrast, spreading of the inoculum on agar surfaces yielded erratic colony counts, attributed to deleterious effects of relatively dry culture medium.

In the standard transformation test, str-r transformants were plated from 30 to $90 \mathrm{~min}$ after initial cellular exposure to DNA; platings were completed before the transformed cells initiated division. A sample (1.0 to $0.1 \mathrm{ml})$ was mixed with $40 \mathrm{ml}$ of str-free HIY-1 soft agar at $44 \mathrm{C}$, and 4-ml aliquots immediately were pipetted on supporting layers $(20 \pm 0.5 \mathrm{ml})$ of 10 HIY-1 hard agar plates (poured several days before and held at room temperature to dry). The overlay agar solidified within $5 \mathrm{~min}$, and plates promptly were placed at $37 \mathrm{C}$ (without stacking); surface moisture occasionally developed, which was allowed to evaporate by judicious partial opening of the inverted plates. Five hr after the time of initial exposure of cells to transforming DNA, plates were removed to room temperature, and were overlaid with a $4-\mathrm{ml}$ top layer of HIY-1 soft agar containing str in a quantity sufficient to give $500 \mu \mathrm{g}$ per $\mathrm{ml}$ after diffusion of the str through the underlying agar. Plates were incubated at $37 \mathrm{C}$ for 3 to 4 days before colonies were counted.

Strain 15 str- $d$, used as recipient for transformation to $s t r-r$ or str-s, was cultivated on HI-1 agar containing $500 \mu \mathrm{g} s t r$ per ml. Nondependent transformants were plated in HIY-1 str-free soft agar, as described; top layers were not added.

Tests of transformant colonies. Several hundred transformants of each class (str-r, str-s, str-d) were identified by suspending a small amount of colonial growth in a drop of sterile broth and streaking corresponding areas of two kinds of HI-1 agar plates, one str-free and the second containing $500 \mu \mathrm{g}$ str per ml. Growth on both plates indicated that the transformant was str-r. Str-d produced visible growth only on the strcontaining agar, and str-s only on str-free agar. Without exception, transformants corresponded to the type of cell from which the transforming DNA had been extracted.
The oxidase reaction was employed as a rapid method for detecting possible contaminant colonies. Most contaminants fail to react, whereas colonies of neisseria rapidly darken in the presence of a 1 per cent solution of dimethyl$p$-phenylenediamine hrdrochloride ( $p$-aminodimethylaniline monohydrochloride, Difco). The reagent readily penetrated to deep colonies when these were stabbed with a sterile needle.

Controls. All transformation tests were accompanied by one or both of two controls: (1) transforming DNA which had been inactivated by addition of crystalline deoxyribonuclease 5 min before adding recipient cells, (2) DNA preparation extracted from the same strain which was to serve as recipient. In other respects these control tests were similar to the transformation tests. Therefore, together, they served to exclude error which might arise from: mutations (spontaneous or, conceivably, induced); selective action on the recipient population of DNA-split products (Firshein and Braun, 1958), or of intact DNA (which lacks the specific genetic marker being investigated); failure of deoxyribonuclease to inactivate transforming DNA; the presence of contamination in any of the solutions. Controls were uniformly negative in the standard test; mutants were encountered in two special cases, as will be indicated.

\section{RESULTS}

Part I. Factors influencing transformation ratios. (1) Phenotypic expression:- I When streptomycinsensitive cells are exposed to transforming DNA extracted from a str-r culture and, shortly thereafter, are challenged with str, few or no transformants resistant to $500 \mu \mathrm{g}$ str per $\mathrm{ml}$ are obtained. Transformation is demonstrated, however, if the same cells are incubated for a period sufficient to allow several divisions in str-free medium before exposure to the antibiotic. This delay in phenotypic expression, which has been recognized for all the transformation systems, creates a methodological problem. On the one hand, each cell which receives a str-r marker must be retained in a suitable str-free environment until resistance has developed. On the other hand, these cells must be placed in solitary confinement before any one of them undergoes division; only thus will each colony indicate an independent genetic event. Under the conditions defined for the pneumococcus system (Hotchkiss, 
TABLE 1

Time required for phenotypic expression of streptomycin-resistance by Neisseria meningitidis strain 15 str-s

A. In Streptomycin-free Broth at $37 \mathrm{C}^{a}$

\begin{tabular}{r|c|c|c}
\hline $\begin{array}{c}\text { Time } \\
\text { sampled }\end{array}$ & $\begin{array}{c}\text { Total viable cells } \\
\text { plated/ml }\end{array}$ & $\begin{array}{c}\text { Str-r cells/ } \\
\mathrm{ml}^{b}\end{array}$ & $\begin{array}{c}\text { Str-r cells/ } \\
\text { one million } \\
\text { viable cells }\end{array}$ \\
\cline { 2 - 3 } $\min$ & & & \\
5 & $4.1 \times 10^{5}$ & 0 & - \\
30 & $6.1 \times 10^{5}$ & 0 & - \\
80 & $1.4 \times 10^{6}$ & 1 & 0.7 \\
110 & $2.4 \times 10^{6}$ & 182 & 76 \\
140 & $4.3 \times 10^{6}$ & 572 & 133 \\
165 & $7.8 \times 10^{6}$ & 1182 & 152 \\
193 & $1.3 \times 10^{7}$ & 2186 & 168 \\
\hline
\end{tabular}

B. In Streptomycin-free Agar at $37 \mathrm{C}^{c}$

\begin{tabular}{c|c}
\hline $\begin{array}{c}\text { Total incubation before } \\
\text { addition of } s t r\end{array}$ & Transformants/ml \\
\hline $\min$ & \\
270 & 472 \\
300 & 547 \\
330 & 546 \\
\hline
\end{tabular}

${ }^{a}$ Cells taken from 17-hr HI-1 agar, suspended in HI-1 broth +0.2 per cent glucose; DNA from strain 15 str $-r 51,5 \mu \mathrm{g} / \mathrm{ml}$, added at time 0 ; deoxyribonuclease added at $15 \mathrm{~min}$.

${ }^{b}$ Assayed $1.0 \mathrm{ml}$ in $39 \mathrm{ml} \mathrm{HIY-1} \mathrm{soft} \mathrm{agar}+500$ $\mu \mathrm{g} s t r / \mathrm{ml}$, overlaid $4 \mathrm{ml} /$ plate on 10 supporting layers HIY -1 hard agar $+500 \mu \mathrm{g} \mathrm{str} / \mathrm{ml}$.

${ }^{c}$ Culture ( $A$, above) sampled at $45 \mathrm{~min}, 3 \mathrm{ml}$ mixed with $117 \mathrm{ml}$ HIY-1 soft agar, overlaid 4 $\mathrm{ml} /$ plate on 30 supporting layers HIY-1 hard agar; at intervals, groups of 10 plates were toplayered with HIY -1 soft agar $+s t r$ to give $500 \mu \mathrm{g}$ $s t r / m l$ after diffusion.

1957), all of the str-r transformants develop resistance in broth during a limited time beginning about 30 min after exposure to DNA, but their division is delayed for another 1 to $2 \mathrm{hr}$. During this interval, the population may be sampled directly into a str-containing medium.

Phenotypic expression was investigated in six experiments with meningococci. Table 1 ( $A$ and $B$ ) shows results of one of these experiments; comparable results were obtained in others, which tested cell suspensions prepared from 15-hr blood agar cultures, and several modifications of the exposure medium (HI-2 broth, with separate omissions of the glucose and the fresh yeast extract). With the media employed, individual cells of a population varied with respect to the period of metabolic activity required before resistance to $500 \mu \mathrm{g} s t r$ per $\mathrm{ml}$ was developed. A few cells became resistant 80 to 90 min after initial exposure to the DNA; no str-r transformants were detected in earlier samples. In the six experiments, expression times for the remaining transformants were distributed over the ensuing 60- to $90-\mathrm{min}$ period (continuous incubation at $37 \mathrm{C}$ ); this is reflected (table $1 A$ ) in the rapid increase of the number of resistant cells per one million total viable cells plated during the 80- to 140-min period. Thereafter, increase of str-r presumably was due largely to division of cells whose resistance was expressed earlier, though a small part of the increase may have been due to longer delay of phenotypic expression.

Since a period of incubation in broth was not found which would provide 100 per cent phenotypic expression without also allowing division of some transformants, the procedure of plating the DNA-treated cells 30 min after application of crystalline deoxyribonuclease was investigated in two of the experiments mentioned above. Table $1 B$ shows results of a test in which phenotypic expression and subsequent division of transformants occurred after the cells were plated in str-free HI-1 soft agar. Top layers of medium containing str were added at intervals. Onehundred per cent phenotypic expression was obtained with an incubation period of $5 \mathrm{hr}$ elapsing between time of initial exposure of cells to DNA and time of addition of streptomycin. In this test, one transformant was detected for every 750 cells exposed to DNA. This plating procedure was employed for subsequent transformation tests.

(2) Cellular competence:-Meningococcus populations exhibited the capacity to become transformed when sampled at intervals during an entire 24-hr period of cultivation in broth at 37 C (table 2). During the lag and logarithmic growth phases, a relatively large proportion of the cells was competent, in comparison with cultures of Haemophilus influenzae (Alexander et al., 1954) and pneumococcus (Hotchkiss, 1954) at correspondingly early hours.

In three experiments with $N$. meningitidis strain 15 str-s, transformation tests were carried out periodically with samples taken from broth 
TABLE 2

Relation between culture age and cellular competence of Neisseria meningitidis strain 15 str-s

\begin{tabular}{|c|c|c|c|c|}
\hline \multicolumn{2}{|c|}{ Culture $^{a}$} & \multicolumn{3}{|c|}{ Transformation Test $^{b}$} \\
\hline $\begin{array}{l}\text { Time } \\
\text { sam- } \\
\text { pled }\end{array}$ & $\begin{array}{l}\text { Total viable } \\
\text { cells } / \mathrm{ml}\end{array}$ & $\begin{array}{c}\text { Total viable } \\
\text { cells/ml ex- } \\
\text { posed to DNA } \\
(E)\end{array}$ & $\begin{array}{l}\text { Str-r } \\
\text { transform- } \\
\text { ants } / \mathrm{ml} \\
(T)\end{array}$ & $\begin{array}{l}(T / E) \\
\times 10^{5}\end{array}$ \\
\hline$h r$ & & & & \\
\hline 0 & $1.5 \times 10^{6}$ & $1.5 \times 10^{6}$ & 1,673 & 112 \\
\hline 1 & $2.9 \times 10^{6}$ & $2.9 \times 10^{6}$ & 4,950 & 171 \\
\hline 2 & $7.2 \times 10^{6}$ & $7.2 \times 10^{6}$ & 12,240 & 170 \\
\hline 3 & $2.0 \times 10^{7}$ & $2.0 \times 10^{7}$ & 39,700 & 199 \\
\hline 4 & $6.9 \times 10^{7}$ & $6.9 \times 10^{7}$ & $-c$ & 一 \\
\hline 5 & $2.0 \times 10^{8}$ & $2.0 \times 10^{6}$ & 4,365 & 218 \\
\hline 6 & $3.9 \times 10^{8}$ & $3.9 \times 10^{6}$ & 8,400 & 215 \\
\hline 7 & $6.2 \times 10^{8}$ & $6.2 \times 10^{5}$ & 1,309 & 211 \\
\hline 8 & $1.1 \times 10^{9}$ & $1.1 \times 10^{6}$ & 1,323 & 120 \\
\hline \multirow[t]{2}{*}{24.5} & $2.8 \times 10^{9}$ & $2.8 \times 10^{9}$ & 2,137 & 0.076 \\
\hline & & $2.8 \times 10^{6}$ & 815 & 29 \\
\hline \multicolumn{5}{|l|}{$\begin{array}{c}\text { Con- } \\
\text { trols : }\end{array}$} \\
\hline 0 & $1.5 \times 10^{6}$ & $1.5 \times 10^{6}$ & 0 & \\
\hline \multirow[t]{2}{*}{24.5} & $2.8 \times 10^{9}$ & $2.8 \times 10^{9}$ & $787^{d}$ & \\
\hline & & $2.8 \times 10^{6}$ & 0 & \\
\hline
\end{tabular}

${ }^{a} \mathrm{HI}-2$ broth inoculated at $0 \mathrm{hr}$ with cellular suspension from 13-hr HI-1 agar culture; incubated at $37 \mathrm{C}$ without aeration.

${ }^{b}$ Three and nine-tenths $\mathrm{ml}$ of culture (undiluted, or diluted with fresh HI-2 broth) mixed at $37 \mathrm{C}$ with $0.1 \mathrm{ml}$ DNA (strain $10 s t r-r$ ), final concentration $2 \mu \mathrm{g} / \mathrm{ml}$; deoxyribonuclease added after $12 \mathrm{~min}$; samples for assay of $T$ plated at 45 min.

${ }^{c}$ Colonies too numerous to count.

${ }^{d}$ Spontaneous str-r mutants developing upon background growth; correction factor used to obtain value of $T$ for corresponding culture.

cultures. In the first experiment (table 2), the number of transformants per $10^{5}$ treated cells $\left((T / E) \times 10^{5}\right)$ ranged from 112 to 218 during the first $8 \mathrm{hr}$, and the value was 29 at the end of $24.5 \mathrm{hr}$. Undiluted samples of the culture were tested at all times and, beginning with the 5 -hr sample, a dilution of the culture in fresh broth also was tested. Although uncountable, the estimated numbers of colonies on transformant plates prepared from the undiluted 5 -hr to 8 -hr samples were roughly in agreement with results obtained with the corresponding diluted samples. In contrast, a countable number of colonies developed, together with a haze of background growth, on plates from the transformation test carried out with the undiluted $24.5 \mathrm{hr}$ culture; the corresponding test, carried out with a 1:1000 dilution of the same culture sample, resulted in a 380 -fold increase in recovery of str- $r$ transformants (in terms of $T$ for the undiluted culture). This resembles the dilution effect shown by Schaeffer (1956) with younger (3 to $4 \mathrm{hr}$ ) cultures of $H$. influenzae.

The early growth phases were reexamined in two experiments. The cultures, in HI-1 broth, were sampled at $30 \mathrm{~min}$ intervals for $5 \mathrm{hr}$, and uniformly were diluted $0.5 \mathrm{ml}$ in $2.0 \mathrm{ml}$ of fresh broth containing the transforming DNA preparation. For one culture, the number of transformants per $10^{5}$ treated cells varied only within the range 125 to 178 ; the second culture, however, gave fluctuating values: 74 at $0 \mathrm{hr}$, increasing to 1241 at $3 \mathrm{hr}$, and thereafter decreasing to about 700. During exponential growth, generation times were 31 and $33 \mathrm{~min}$ for the cultures in HI-1 broth, and $36 \mathrm{~min}$ for the culture in HI-2 broth.

TABLE 3

Effects of concentration of DNA and time of exposure on transformation of Neisseria meningitidis to streptomycin-resistance ${ }^{a}$

\begin{tabular}{l|c|c|c}
\hline \multicolumn{2}{c|}{ Deoxyribonucleate } & $\begin{array}{c}\text { Transform- } \\
\text { ants/ml } \\
(T)\end{array}$ & $(T / E) \times 10^{5}$ \\
\cline { 1 - 2 } Conc & Exposure time & \\
\hline$\mu g / m l$ & & & \\
5.0 & 15 & 479 & 399 \\
2.0 & 15 & 410 & 342 \\
1.0 & 15 & 330 & 275 \\
0.5 & 15 & 306 & 255 \\
0.1 & 15 & 198 & 165 \\
0.01 & 15 & 36 & 30 \\
0.001 & 15 & 7 & 6 \\
\hline 2.0 & 10 & 246 & 205 \\
2.0 & 5 & 131 & 109 \\
2.0 & 2 & 44 & 37 \\
2.0 & 1 & 30 & 25 \\
2.0 & + & 1301 & 1083 \\
\hline
\end{tabular}

${ }^{a}$ Strain 15 str-s, from $16-\mathrm{hr}$ culture on HI-1 agar, suspended in HI-2 broth; $1.2 \times 10^{5}$ cells $/ \mathrm{ml}$ $(E)$ were exposed at $36 \mathrm{C}$ to DNA (from strain 10 str-r).

${ }^{b}$ Exposure to effective DNA terminated by deoxyribonuclease, except for " + "' where cells were plated, after 50 -min exposure, without added enzyme. 


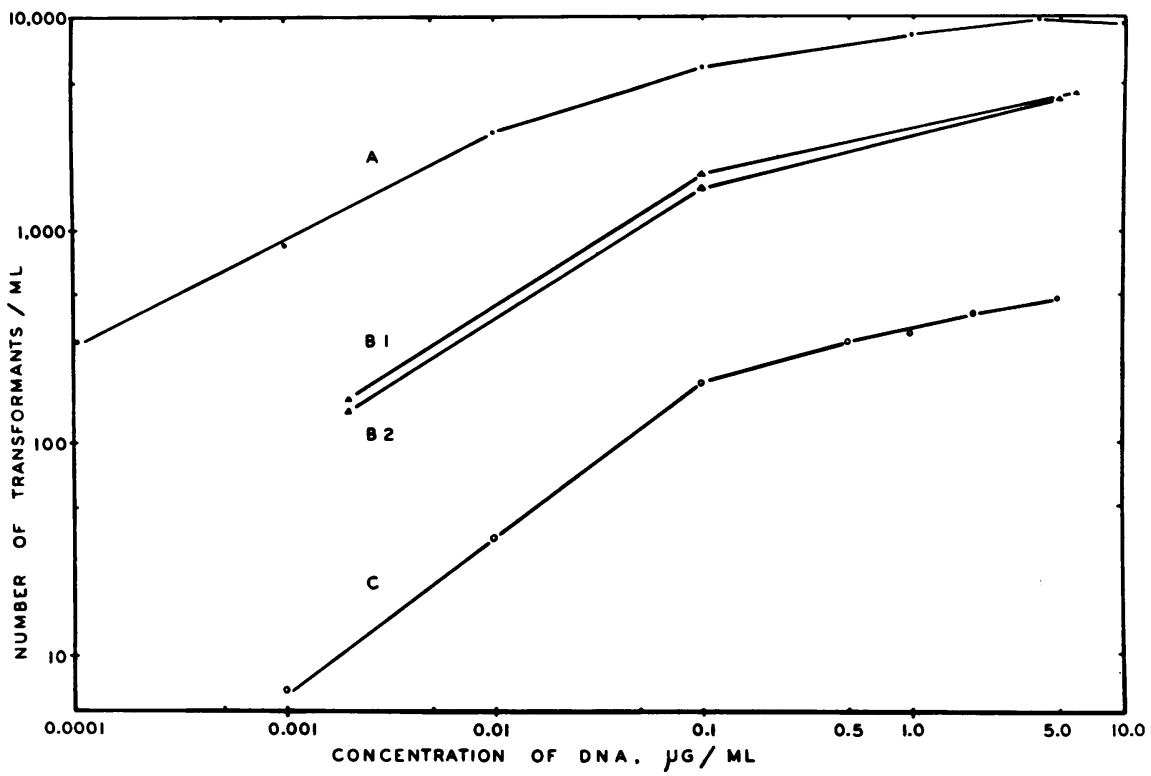

Figure 1. Concentration-response curves of Neisseria meningitidis str- $r$ transformants plotted against concentration of transforming DNA preparation (both logarithmic). Curve A: transformation of strain 15 str- $d\left(4.0 \times 10^{6}\right.$ viable "cells" /ml) by DNA from strain 15 str-r 51 . Curves B1 and B2: transformation of strain 15 car-r str-s by DNA preparations (intracellular, B1; extracellular, B2) from strain 15 str- $r$ 51 (table 5). Curve C: transformation of strain 15 str-s by DNA from strain 10 str-r (table 3).

(3) DNA concentration:-The relation between yield of transformants and DNA concentration has been examined for each of the recipient strains, and for the various DNA preparations. Results obtained with a preparation of intracellular DNA from strain 10 str- $r$ are shown in table 3. A suspension containing $1.2 \times 10^{5}$ colony-forming units per $\mathrm{ml}$ of strain $15 \mathrm{str}-\mathrm{s}$ provided the recipient cells. Use of a denser suspension, in other experiments, demonstrated transforming activity in lower concentrations of this same DNA preparation, and the shapes of the concentration-response curves were the same.

For purposes of comparison with other concentration-response curves, data of table 3 (15-min exposures) are plotted in figure $1(C)$. Curves $B 1$, $B \mathscr{2}$, and $C$, which delineate transformation from $s t r-s$ to $s t r-r$, are essentially parallel in spite of differences relating both to the DNA-donor and to the number and kind of recipient cells. A linear relation in the range below $0.1 \mu \mathrm{g}$ DNA per $\mathrm{ml}$ was found, as expected on the basis of results with other transformation systems (Alexander et al., 1954; Hotchkiss, 1957; Spizizen, 1958).

Cellular capacity for response to DNA is "saturated" when concentrations of DNA between 5 to $10 \mu \mathrm{g}$ per $\mathrm{ml}$ are present for $15 \mathrm{~min}$ before addition of deoxyribonuclease. Higher concentrations of DNA usually did not increase the yield of str-r transformants in samples of a given population. This is shown in figure $1(A)$ for transformation of the streptomycin-dependent strain to nondependence (str-r), where $4.0 \mu \mathrm{g}$ DNA per ml elicited 248 transformants per $10^{5}$ exposed cells. DNA concentrations of 10.0 and $1.0 \mu \mathrm{g}$ per $\mathrm{ml}$ both elicited slightly fewer transformants.

(4) Time of exposure to DNA:-Transforming DNA is taken up by competent cells and bound in some manner which protects it from destruction by added crystalline deoxyribonuclease (Lerman and Tolmach, 1957). This process was completed in less than $1 \mathrm{~min}$ by some cells of an exposed meningococcus population, as shown in table 3 . The number of transformants increased linearly with time of exposure to transforming DNA during the initial $15 \mathrm{~min}$. When deoxyribonuclease was not added, and the cells were plated after an exposure period of $50 \mathrm{~min}$, over 1 per cent of the population became transformed.

A standard exposure time of $15 \mathrm{~min}$ before 
addition of deoxyribonuclease was arbitrarily chosen (Hotchkiss, 1957) for most of the experiments described in Part II, although a longer time would have increased the yield of transformants.

Part II. Transformation by extracellular DNA. Early investigators recognized the rapid loss of viability characteristic of meningococcus cultures, and the necessity for frequent subcultures. Flexner (1907) observed a progressive appearance of swollen forms, loss of staining, and disintegration of meningococci during a 2- to 3-day period of incubation. These changes, which were attributed to the action of an autolytic enzyme, were shown to be accelerated by desiccation of the surface of agar media, and to be delayed by addition of calcium to an otherwise suitable medium.

Strain 15 employed in the present investigation, likewise, is subject to rapid loss of viability, both on agar and in broth. The composition of the medium and degree of aeration were important, as would be expected, in determining both the inoculum size required for initiating growth and the characteristics of subsequent growth phases. A population size of over $10^{9}$ colony-forming units per $\mathrm{ml}$ commonly was maintained well beyond $24 \mathrm{hr}$ in an appropriately supplemented heart infusion broth (table 2). However, with heart infusion broth supplemented only with 0.2 per cent glucose, or with brain heart infusion, an inoculum of $10^{6}$ viable cells per $\mathrm{ml}$, and aeration, were required for initiation of growth; moreover, loss of viability of some cultures exceeded 3 logarithmic decades within $24 \mathrm{hr}$ (table 4). When such cultures were removed from the shaker at $16 \mathrm{hr}$, but were retained at $37 \mathrm{C}$, a slimy sediment gradually accumulated without experimental intervention. The time of appearance and extent of accumulation of slime varied somewhat in cultures of the same strain, possibly owing to differences in rate of decline of culture viability. Commonly, however, slime could be detected within $24 \mathrm{hr}$ as a film adherent to the glass; 5 to $10 \mathrm{ml}$ of thick, tenacious material often could be aspirated with a pipette from the bottom of a $300-\mathrm{ml}$ culture within 2 to 4 days.

Extracellular DNA preparations from cultures of strain 15 str-r, which had been incubated at $37 \mathrm{C}$ for 2 to 4 days, were found in preliminary experiments using strain $15 \mathrm{str}-\mathrm{s}$ and $s t r-d$ as recipients to have transforming activities comparable to those of intracellular DNA preparations. This raised the question whether the crude slime has similar transforming activity.

To eliminate viable str-r slime-donor cells without affecting the slime which was the source of transforming DNA, an antibiotic (either erythromycin or carbomycin) was employed which inhibited the growth of donor cells, but not of recipient cells. This antibiotic was incorporated in all culture media used in the transformation test after exposure of recipient cells to slime. Thus, cells to be transformed were in contact with the slime in the usual antibioticfree medium. The presence of the extra antibiotic did not interfere with the selective action of streptomycin, added subsequently. The competence of recipient strains (resistant to $3 \mu \mathrm{g}$ ery per $\mathrm{ml}$ or to $50 \mu \mathrm{g}$ car per $\mathrm{ml}$ ) was somewhat reduced in comparison with that of the sensitive parent strain 15 under the same conditions. Because of its higher level of resistance, the car-r strain was used where the slime was expected to contain numerous viable cells. Each dilution of slime (in heart infusion broth) tested for transforming activity was examined also in a control test (crystalline deoxyribonuclease added to the slime 5 min prior to contact with recipient cells). Control plates were negative in all tests, except one (table $4, \mathrm{~B}, 3$ ) where the slime had contained enough viable cells to provide the opportunity for mutation to erythromycin ( $1 \mu \mathrm{g}$ per $\mathrm{ml}$ ) resistance ( $T$ was corrected, accordingly).

Results of three experiments employing the ery-r strain as recipient are compiled in table 4 . Transforming capacity of crude slime, in final dilutions of $1: 5$ to $1: 25$, was equal to or slightly greater than that of a partially purified preparation of extracellular DNA, which was tested in each experiment at a concentration of $5 \mu \mathrm{g}$ per $\mathrm{ml}$ (and, also, in lower concentrations in experiment C), as shown by the ratio $T$ (slime) to $T$ (DNA, $5 \mu \mathrm{g}$ per $\mathrm{ml}$ ). Thus, procedures for extracting and deproteinizing the DNA were not required for demonstrating transforming activity of culture slime.

To determine whether transforming activity of slime would decline with storage at room temperature, undiluted slime retained in a tightly capped sterile tube was retested (table 4, C, 4) 7 days after the initial test $(B, 4)$. Transforming activity of the 1:25 dilutions examined in the 
TABLE 4

Transforming activity of slime DNA accumulating in meningococcus cultures of various ages

\begin{tabular}{|c|c|c|c|c|c|c|c|}
\hline \multirow[b]{2}{*}{ Expt } & \multicolumn{3}{|c|}{ Culture (strain 15 str-r ery-s) ${ }^{a}$} & \multicolumn{4}{|c|}{ Transformation Test ${ }^{b}$} \\
\hline & No. & $\begin{array}{c}\text { Incubation } \\
\text { time }\end{array}$ & Total viable cells $/ \mathrm{ml}$ & $\begin{array}{l}\text { Culture slime } \\
\text { (final dilution) }\end{array}$ & $T$ & $\underset{10^{5}}{(T / E)} \times$ & $\frac{T \text { (slime) }}{T\left(\begin{array}{c}\text { (DNA) } \\
5 \mu \mathrm{mg} / \mathrm{ml})\end{array}\right.}$ \\
\hline A & $\begin{array}{l}1 \\
2 \\
2 \\
2\end{array}$ & $\begin{array}{c}k r \\
72 \\
9 \\
24 \\
47\end{array}$ & $\begin{array}{l}5.0 \times 10^{1} \\
5.1 \times 10^{8} \\
3.2 \times 10^{5} \\
1.5 \times 10^{2}\end{array}$ & $\begin{array}{c}1: 5 \\
- \\
1: 8\end{array}$ & $\begin{array}{r}1678^{c} \\
380\end{array}$ & 258 & $\begin{array}{l}4.44 \\
1.01\end{array}$ \\
\hline B & $\begin{array}{l}3 \\
3 \\
3 \\
4\end{array}$ & $\begin{array}{r}24 \\
45 \\
45 \\
144\end{array}$ & $\begin{array}{c}1.4 \times 10^{7} \\
3.0 \times 10^{5} \\
3.0 \times 10^{5} \\
0\end{array}$ & $\begin{array}{l}- \\
1: 5 \\
1: 25 \\
1: 25\end{array}$ & $\begin{array}{r}886 \\
830 \\
1068\end{array}$ & $\begin{array}{l}74 \\
69 \\
89\end{array}$ & $\begin{array}{l}1.01 \\
0.95 \\
1.22\end{array}$ \\
\hline $\mathrm{C}$ & $\begin{array}{l}4 \\
5 \\
5 \\
5\end{array}$ & $\begin{array}{c}144^{d} \\
92 \\
92 \\
92^{e}\end{array}$ & $\begin{array}{l}0 \\
0 \\
0 \\
0\end{array}$ & $\begin{array}{l}1: 25 \\
1: 5 \\
1: 25 \\
1: 5\end{array}$ & $\begin{array}{l}554 \\
597 \\
540 \\
620\end{array}$ & $\begin{array}{l}71 \\
77 \\
69 \\
80\end{array}$ & $\begin{array}{l}1.09 \\
1.18 \\
1.07 \\
1.23\end{array}$ \\
\hline & DNA & - & - & $\begin{array}{c}\mathrm{DNA}, \mu \mathrm{g} / \mathrm{ml} \\
5.0 \\
0.5 \\
0.05 \\
0.005\end{array}$ & $\begin{array}{r}506 \\
386 \\
161 \\
60\end{array}$ & $\begin{array}{r}65 \\
50 \\
21 \\
8\end{array}$ & $\begin{array}{l}- \\
- \\
-\end{array}$ \\
\hline
\end{tabular}

${ }^{a}$ Cultures 1 to 4 in brain heart infusion; 5 in heart infusion with 0.2 per cent added glucose; incubated at $37 \mathrm{C}$, on shaker for original $18 \mathrm{hr}$. DNA = extracellular DNA harvested at $76 \mathrm{hr}$ from supernatant broth of culture 1 (experiment $\mathrm{A}$ ), and deproteinized.

${ }^{b}$ Recipient cells, strain 15 str-s ery-r, from 15 -hr cultures on HI-1 agar $+1.0 \mu \mathrm{g} \mathrm{ery} / \mathrm{ml}$, were suspended in heart infusion broth; $2.0 \mathrm{ml}$ was mixed at $36 \mathrm{C}$ with $0.5 \mathrm{ml}$ of culture slime (or DNA); $\mathrm{E}$ (number of recipient cells $/ \mathrm{ml}$ exposed to DNA) $6.5 \times 10^{5}$ for experiment A, $1.2 \times 10^{6}$ for $\mathrm{B}, 7.8 \times 10^{5}$ for C. Deoxyribonuclease added after $15 \mathrm{~min}$, except in experiment A, 1. T (number of str-r transformants $/ \mathrm{ml}$ ) assayed in HIY-1 soft agar $+1.0 \mu \mathrm{g} e r y / \mathrm{ml}$; top layer, same + str (to give $500 \mu \mathrm{g}$ $s t r / \mathrm{ml}$ after diffusion).

${ }^{c}$ Sample plated after 50 min exposure without added deoxyribonuclease.

${ }^{d}$ Slime aspirated aseptically from 144 -hr culture $(\mathrm{B}, 4)$, stored at room temp for 7 days, and retested.

${ }^{e}$ Undiluted slime heated at $80 \mathrm{C}( \pm 0.1 \mathrm{C})$ for $30 \mathrm{~min}$, immediately cooled, and tested.

two tests exceeded that of the DNA preparation, used at $5 \mu \mathrm{g}$ per ml. Thus, a deoxyribonuclease highly active against slime DNA was not released under these conditions.

Several lines of reasoning suggest the necessity for investigating possible deoxyribonuclease activity in meningococcus cultures: (1) When bacteria release DNA, they might also release intracellular deoxyribonuclease. (2) Extracts of sonically disintegrated meningococci contain a deoxyribonuclease which, although highly active against several DNA preparations, exhibited little activity in viscometric tests against menin- gococcus DNA preparations (Catlin, 1959). This or another deoxyribonuclease might become active under certain special conditions. (3) Cultures of meningococci grown under apparently similar conditions do not become equally slimy. Consequently, the activity of slime accumulating in unusually small amounts was investigated.

Table 5 shows the transforming activity of slime from a culture in brain heart infusion (300 $\mathrm{ml}$ in $1000-\mathrm{ml}$ flask) incubated at $37 \mathrm{C}$ for $116 \mathrm{hr}$ (with shaking for the first $19 \mathrm{hr}$ ). The turbid broth was decanted from a slight film of slime clinging to the bottom of a flask. The slime was 
TABLE 5

Transforming activity of culture slime and DNA preparations from Neisseria meningitidis strain 15 str-r $51^{a}$

\begin{tabular}{|c|c|}
\hline Material Tested & $\begin{array}{l}\text { Transform- } \\
\text { ants/ml }\end{array}$ \\
\hline \multirow{3}{*}{$\begin{array}{l}\text { Crude slime, } 116 \text {-hr culture: } \\
1: 5 \text { dilution } \ldots \ldots \ldots \ldots \ldots \ldots \ldots \ldots \ldots \\
1: 5 \text { dilution }(\text { control })^{b} \ldots \ldots \ldots \ldots \ldots\end{array}$} & \\
\hline & 4120 \\
\hline & 0 \\
\hline $1: 100$ dilution $\ldots \ldots \ldots \ldots \ldots$ & 1612 \\
\hline $1: 100$ dilution (control) $)^{b} \ldots \ldots$ & 0 \\
\hline \multicolumn{2}{|l|}{ Extracellular DNA solution, $\mu \mathrm{g} / \mathrm{ml}$ : } \\
\hline $5.0 \ldots \ldots \ldots \ldots \ldots \ldots \ldots \ldots \ldots \ldots \ldots \ldots \ldots \ldots$ & 4237 \\
\hline $0.1 \ldots \ldots \ldots \ldots \ldots \ldots \ldots \ldots$ & 1611 \\
\hline $0.002 \ldots \ldots \ldots \ldots \ldots \ldots \ldots \ldots \ldots \ldots \ldots \ldots \ldots \ldots$ & 142 \\
\hline \multicolumn{2}{|l|}{ Intracellular DNA solution, $\mu \mathrm{g} / \mathrm{ml}$ : } \\
\hline $6.0 \ldots \ldots \ldots \ldots \ldots \ldots \ldots \ldots \ldots \ldots \ldots \ldots \ldots \ldots$ & 4513 \\
\hline $0.1 \ldots \ldots \ldots \ldots \ldots \ldots$ & 1900 \\
\hline $0.002 \ldots \ldots \ldots$ & 162 \\
\hline 6.0 (control $)^{b}$. & 0 \\
\hline
\end{tabular}

a DNA solution or culture slime, $0.5 \mathrm{ml}$, was mixed at $36 \mathrm{C}$ with $2.0 \mathrm{ml}$ suspension in $\mathrm{HI}-1$ broth of recipient cells (strain 15 car-r str-s, $6.1 \times 10^{6}$ viable cells $/ \mathrm{ml}$ exposed); deoxyribonuclease added after $15 \mathrm{~min}$; transformants plated in HIY-1 soft agar $+20 \mu \mathrm{g} c a r / m l$; top layer of same medium + str (to give $500 \mu \mathrm{g} s t r / \mathrm{ml}$ after diffusion) added at $5 \mathrm{hr}$.

${ }^{b}$ Deoxyribonuclease added 5 min before mixing with cells.

dislodged by vigorous mixing with $2 \mathrm{ml}$ of sterile heart infusion broth. An assay of this slime mixture revealed $1.7 \times 10^{7}$ colony-forming units per ml. As in other cultures, extracellular DNA was present at a concentration sufficient to elicit approximately the same number of transformants as were obtained with transforming DNA preparations from extracellular and from intracellular locations, tested in the same experiment at concentrations of 5.0 and $6.0 \mu \mathrm{g}$ DNA per $\mathrm{ml}$. Results obtained with these two DNA preparations are plotted in figure $1(B 1, B 2)$ to show their similarity to curves obtained using different strains as recipients and as DNA-donors.

\section{DISCUSSION}

The work which has been described was initiated to investigate the structural integrity of extracellular DNA. DNA separated by alcohol precipitation from the supernatant broth of centrifuged slimy meningococcus cultures, and subsequently purified, was genetically active. That such DNA actually was extracellular, rather than merely being liberated during experimental manipulation of the culture, was verified by the capacity of crude culture slime to elicit transformation as a result of less than 15 min contact with recipient meningococci. The similarity of transforming activities of DNA preparations from intracellular and from extracellular locations indicates that DNA may remain in the extracellular environment for some time with little or no destruction of the information-bearing molecular structure.

The possibility that the genetic change elicited by crude culture slime is the result of a process of conjugation or of virus-mediated transduction, rather than of transformation, appears unlikely in view of the susceptibility of the agent to the action of deoxyribonuclease, and the high frequency of the genetic event. Moreover, transforming activity was retained by crude slime which had been heated for 30 min at $80 \mathrm{C}$ (table 4, C, 5); this finding was not unexpected, in view of the heat stability of purified preparations of $H$. influenzae transforming DNA (Zamenhof et al., 1953).

Hotchkiss (1951) suggested that conditions for transformation with lysates might arise in nature. Transformation was obtained in a mixture of two strains of pneumococci; one was penicillinsensitive and streptomycin-resistant, the other was pen-r and str-s. Addition of penicillin resulted in lysis of pen-s cells, whose DNA thereupon transformed the pen-r cells to str-r.

Likewise, transformation of meningococei by the DNA of slime which forms spontaneously may occur in nature. This would require the simultaneous presence of genetically active extracellular DNA, competent cells, and conditions for uptake of the DNA. Although the optimum conditions for the development of cellular competence may not be the same as those required for uptake of transforming DNA, they are not mutually exclusive. Thus, capacity to become transformed was maintained by a considerable fraction of meningococci during an entire 24-hr period of cultivation (table 2). Competence was demonstrated not only when the aging cells were diluted into a fresh medium containing transforming DNA, but also when a small amount of DNA preparation was added to the 
8-hr or 24-hr culture. These findings provide a basis for the idea that natural variation of meningococci, and perhaps other bacteria, may be enhanced through the agency of transformation. Some meningococci which differ by one or more genes from other members of a heterogeneous population may survive in an environment in which slime DNA is accumulating. Competent cells taking up extracellular DNA at random may construct new genetic combinations, thereby increasing the range of adaptibility of the total population.

The transformation method described for meningococcus is reproducible, and satisfies minimal requirements for a quantitative system (Hotchkiss, 1957). The factors which influence the yield of transformants have not been investigated sufficiently, however, to justify comparisons with other transformation systems, beyond those previously indicated. Experiments with defined media, which are in progress, may elucidate factors contributing to competence of meningococci, and thereby provide a basis for increasing transformation ratios.

\section{SUMMARY}

Highly polymerized deoxyribonucleate (DNA) is a component of the slime which may accumulate in cultures of Neisseria meningitidis as cellular viability declines. To investigate possible genetic activity of such extracellular DNA, a quantitative transformation method was developed. Various factors were studied which influence transformation of streptomycin-sensitive meningococci to streptomycin resistance: cellular competence, time of exposure and concentration of transforming DNA, and phenotypic expression. Transformation of a streptomycindependent meningococcus strain to nondependence, also, was studied.

Extracellular DNA was separated by ethanol precipitation from the supernatant broth of centrifuged slimy cultures (streptomycin-resistant strain cultivated in brain heart infusion broth at $37 \mathrm{C}$ for 2 to 4 days). Intracellular DNA was extracted from detergent-lysed cells. Solutions of partially purified DNA preparations obtained from the two locations exhibited similar transforming activities. Moreover, crude culture slime, in dilutions as high as $1: 25$, elicited about the same number of transformants as were obtained using transforming DNA preparations, tested at a concentration of $5 \mu \mathrm{g}$ DNA per ml. Thus, procedures for extracting and purifying the DNA were not required for demonstrating transforming activity of extracellular DNA. The possibility was discussed that natural variation of meningococci, and perhaps of other bacteria, may be enhanced through the agency of transformation by slime layer DNA.

\section{REFERENCES}

Alexander, H. E. And Redman, W. 1953 Transformation of type specificity of meningococci. J. Exptl. Med., 97, 797-806.

Alexander, H. E., Leidy, G., and Hahn, E. 1954 Studies on the nature of Hemophilus influenzae cells susceptible to heritable changes by desoxyribonucleic acids. J. Exptl. Med., 99, 505-533.

Catlin, B. W. 1956a The formation of extracellular deoxyribonucleic acid by various bacteria. Bacteriol. Proc., 1956, 123.

Catrin, B. W. $1956 b$ Extracellular deoxyribonucleic acid of bacteria and a deoxyribonuclease inhibitor. Science, 124, 441-442.

Catlin, B. W. 1959 Activities of deoxyribonucleates and of a deoxyribonuclease from meningococcus. Bacteriol. Proc., 1959, 28-29.

Catlin, B. W. and Cunningham, L. 1958 Studies of extracellular and intracellular bacterial deoxyribonucleic acids. J. Gen. Microbiol., 19, 522-539.

Dische, Z. 1955 Color reactions of nucleic acid components. In The nucleic acids, vol. I, pp. 285-305. Academic Press, Inc., New York.

Firshein, W. and Braun, W. 1958 On the nature of the selective effects of deoxyribonucleic acid digests upon pneumococci of different virulence. Proc. Natl. Acad. Sci. U. S., 44, 918-923.

Flexner, S. 1907 Contributions to the biology of Diplococcus intracellularis. J. Exptl. Med., 9, 105-141.

Нотснкiss, R. D. 1951 Transfer of penicillin resistance in pneumococci by the desoxyribonucleate derived from resistant cultures. Cold Spring Harbor Symposia Quant. Biol., 16, 457-461.

Hotchkiss, R. D. 1954 Cyclical behavior in pneumococcal growth and transformability occasioned by environmental changes. Proc. Natl. Acad. Sci. U. S., 40, 49-55.

Hotchkiss, R. D. 1957 Criteria for quantitative genetic transformation of bacteria. In Chemical basis of heredity, pp. 321-335. Johns Hopkins Press, Baltimore.

Lerma N, L. S. and Tolmach, L. J. 1957 Genetic 
transformation. I. Cellular incorporation of DNA accompanying transformation in pneumococcus. Biochim. et Biophys. Acta, 26, 68-82.

Miller, C. P. And Bohnhoff, M. 1947 Two streptomycin-resistant variants of meningococcus. J. Bacteriol., 54, 467-481.

SchaffFer, P. 1956 Transformation interspécifique chez des bactéries du genre Hemophilus. Ann. inst. Pasteur, 91, 192-211.

Smithies, W. R. And Gibbons, N. E. 1955 The deoxyribose nucleic acid slime layer of some halophilic bacteria. Can. J. Microbiol., 1, 614-621.

Spizizen, J. 1958 Transformation of biochemi- cally deficient strains of Bacillus subtilis by deoxyribonucleate. Proc. Natl. Acad. Sci. U.S., 44, 1072-1078.

SzYBALSKI, W. 1952 Microbial selection. I. Gradient plate technique for study of bacterial resistance. Science, 116, 46-47.

Takahashi, I. and Gibbons, N. E. 1957 Effect of salt concentration on the extracellular nucleic acids of Micrococcus halodenitrificans. Can. J. Microbiol., 3, 687-694.

Zamenhof, S., Alexander, H. E., And Leidy, G. 1953 Studies on the chemistry of the transforming activity. I. Resistance to physical and chemical agents. J. Exptl. Med., 98, 373-397. 